\title{
Constraints on backstop geometry of the southwest Ryukyu subduction based on reflection seismic data
}

\author{
Y. Font ${ }^{\mathrm{a}, *}$, C.-S. Liu ${ }^{\mathrm{a}}$, P. Schnurle ${ }^{\mathrm{b}}$, S. Lallemand ${ }^{\mathrm{c}}$ \\ anstitute of Oceanography, National Taiwan University, P.O. Box 23-13, Taipei, Taiwan, ROC \\ ${ }^{\mathrm{b}}$ Exploration and Development Research Institute, Chinese Petroleum Corporation, Miao-Li, Taiwan, ROC \\ ${ }^{\mathrm{c}}$ UMR CNRS-UM2 5573, Laboratoire de Géophysique, Tectonique et Sédimentologie, ISTEEM, case 60, place E. Bataillon, 34095 Montpellier, \\ France
}

Received 15 October 1999; revised 10 May 2000

\begin{abstract}
Based on the analysis of 45 seismic reflection profiles, the top of the Ryukyu Arc basement is mapped in the forearc region east of Taiwan. The Ryukyu Arc slope dips $10^{\circ}$ trenchward, while beneath the forearc basins, the arc basement shows a series of morphologic along-arc 'highs-and-lows'. One of the basement highs, the Nanao basement rise, has been described as an area uplifted by the subduction of the Gagua Ridge. The other one, the Hoping basement rise, is suggested in this study to be an uplifted feature caused by the subduction (or the underplating) of some local asperity. The nature of this asperity could either be a detached block of the Luzon Arc, an isolated seamount or some material removed from the frontal part (southernmost extremity) of the Ryukyu margin.

From seismic reflection profiles, we infer that the right-lateral transcurrent fault system located at the rear of the accretionary wedge defines the surface projection of the southern termination of the Ryukyu Arc basement. Two crustal sections across the Ryukyu subduction system demonstrate that the backstop terminates in the form of a near-vertical 'wall' with its height over $5 \mathrm{~km}$. Such an unusual geometry could be produced by crustal truncation at the toe of the backstop. (C) 2001 Elsevier Science B.V. All rights reserved.
\end{abstract}

Keywords: Taiwan; southernmost Ryukyu forearc system; seismic reflection; Ryukyu basement geometry

\section{Geodynamic setting}

The orogen of Taiwan is located between two subduction zones dipping in opposite direction (Angelier, 1986). To the south, along the Manila Trench, the Eurasia plate subducts below the Philippine Sea plate thus originating the Luzon volcanic arc (Fig. 1). To the east, the Philippine Sea plate is subducting below the Eurasia plate along the Ryukyu Trench. The Philippine Sea plate, carrying the Luzon Arc, is

\footnotetext{
* Corresponding author.
}

converging toward Taiwan at a rate of $8.1 \mathrm{~cm} /$ year along the azimuth $306^{\circ}$ (Yu et al., 1997). Most of the authors (Biq, 1972; Suppe, 1976, 1981; Ho, 1986; Angelier et al., 1990; Teng et al., 1992) agree that the orogen of Taiwan results from the collision of the Luzon Arc against the passive Chinese continental margin. The suture zone, between the deformed Chinese margin and the emerged Luzon Arc (i.e. the Coastal Range), is represented onland by the Longitudinal Valley (Barrier and Angelier, 1986). The collision process is very young, probably started less than $5 \mathrm{Ma}$ ago (Wu, 1978; Suppe, 1981; Angelier et al., 


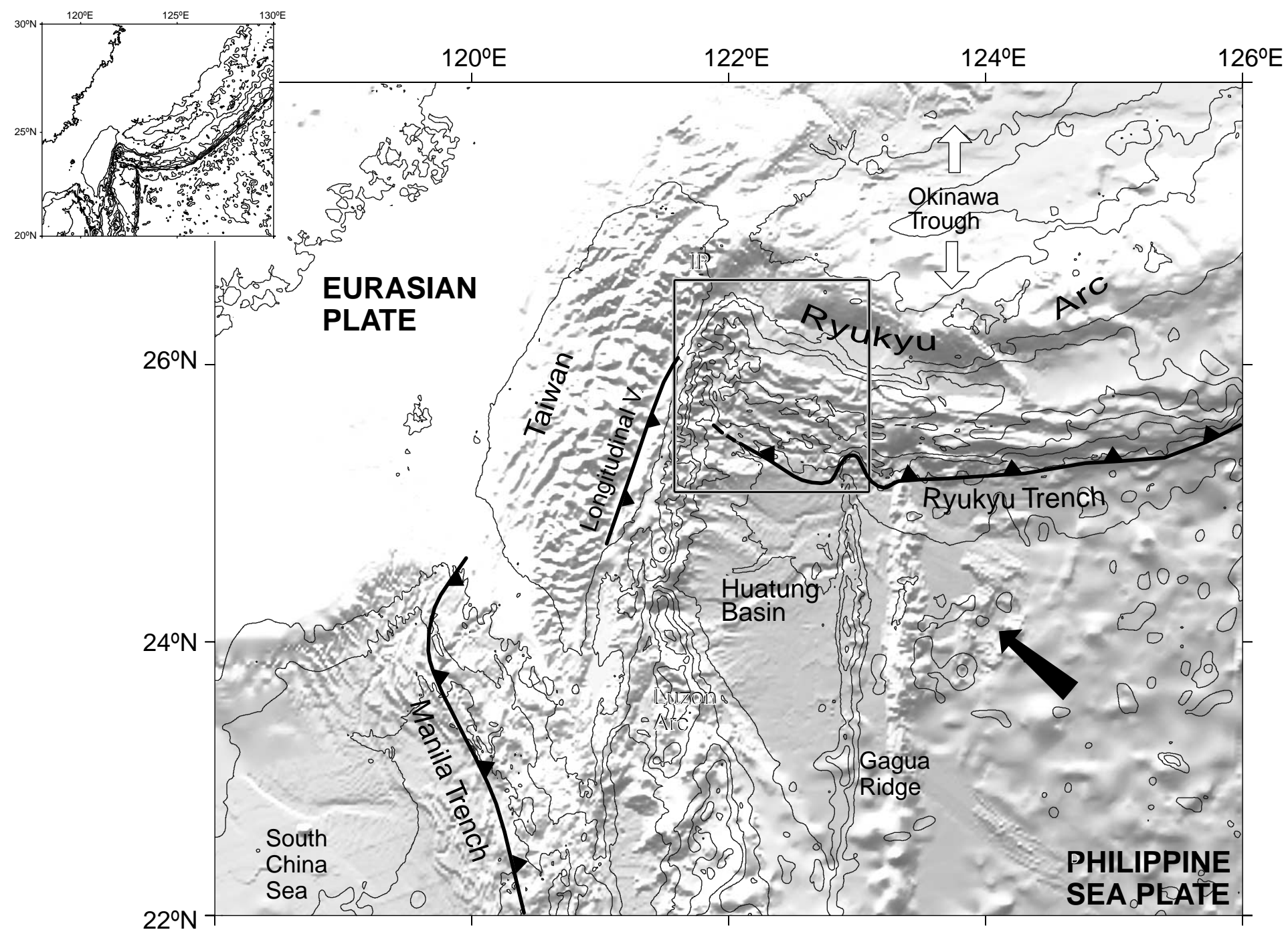

Fig. 1. Geodynamic setting of Taiwan. The black arrow indicates the direction of relative plate motion after Yu and Kuo, 1999. The bold lines with triangles represent the plate boundaries. The white divergent arrows show the extension of the backarc basin. IP = Ilan plain. The enclosed map shows the change of strike of the Ryukyu Trench from Kyushu to Taiwan. The squared area off east Taiwan is the studied area. The dashed line corresponds to the possible extension of the transcurrent fault. 


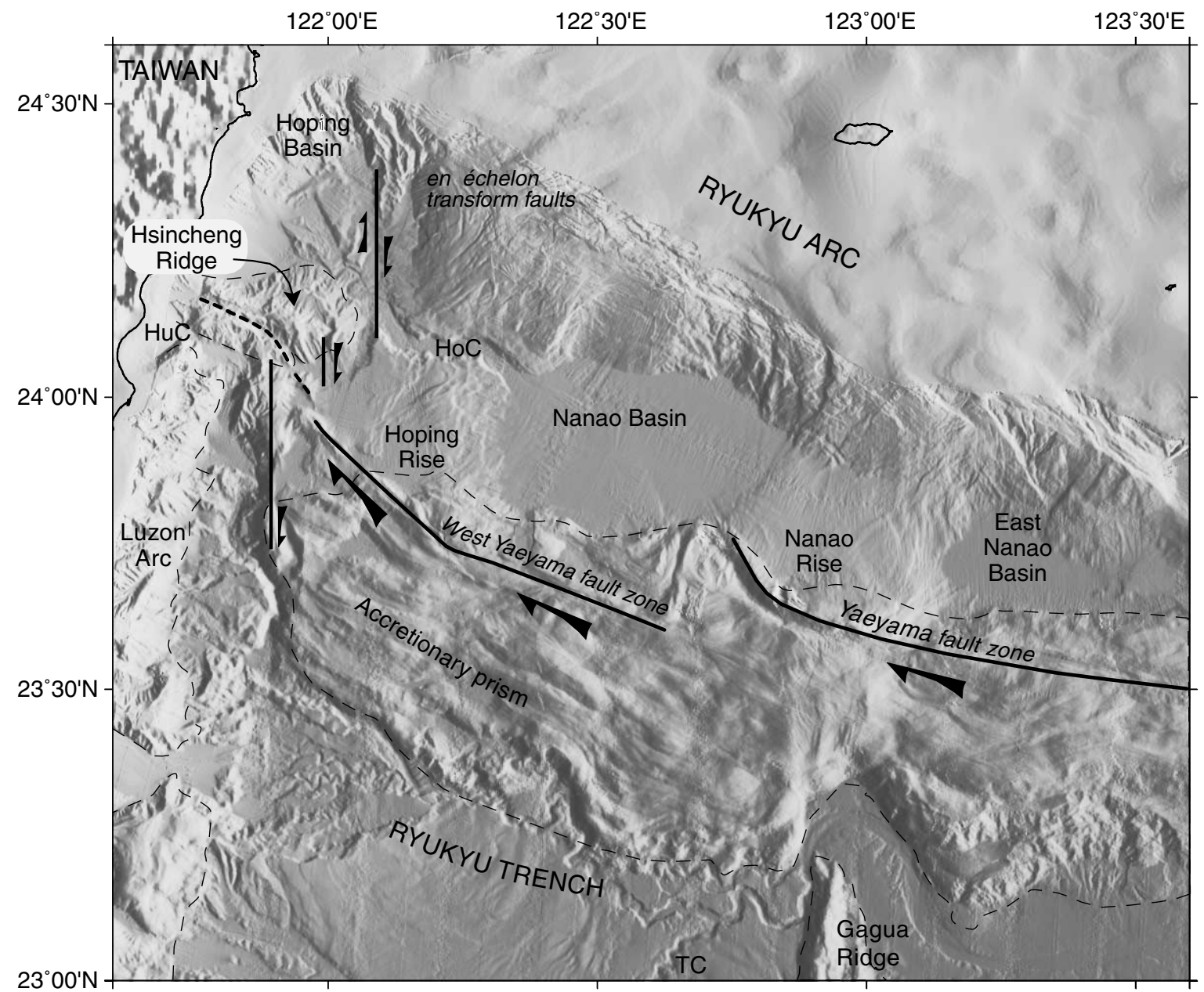

Fig. 2. Detailed bathymetry map of the southernmost Ryukyu forearc region (see location in Fig. 1). HuC $=$ Hualien Canyon, HoC $=$ Hoping Canyon, TC = Taitung Canyon. Two major sets of faults are marked: the en échelon $\mathrm{N}-\mathrm{S}$ transform faults caused by the opening of the Okinawa Trough and the ENE-WSW- to NE-SW-trending transcurrent fault zone due to the oblique subduction.

1990; Teng, 1990). Because the relative convergent motion is northwestward and the Chinese continental margin strikes NE-SW, the collision migrates progressively toward the south (Suppe, 1981). Nowadays, onland GPS measurements show that most of the convergence is accommodated south of $23^{\circ} 40^{\prime} \mathrm{N}$ (Yu et al., 1997). North of this latitude, the island is almost stable and even records some extension in the Ilan Plain area (see Fig. 1 for location).

The Ryukyu subduction system extends from Kyushu in the north to the Taiwan collision zone in the south. Morphologically, it appears as a NE-SWtrending, typical arched trench-arc-backarc basin system, namely the Ryukyu Trench, the Ryukyu Arc and the Okinawa Trough, respectively (Park et al., 1998). Dating studies on arc volcanism north of Taiwan and on neighboring offshore regions revealed a late Plio-Pleistocene age (Juang and Bellon, 1984; Teng et al., 1992). This age is consistent with the seismicity observation showing a slab down to $300 \mathrm{~km}$ depth (Kao et al., 1998; Font et al., 1999). Tomographic images agree with seismicity that the westernmost extremity of the Philippine Sea slab reaches about $120 \mathrm{~km}$ depth under northern Taiwan (Rau and Wu, 1995; Wu et al., 1997). At the transition between the subduction and the collision zones, the 
top of the slab becomes shallower and distorted significantly (Font et al., 1999). However, the most highly concentrated group of earthquakes of the area takes place just east of this deformation zone, below the northwestern part of the Nanao Basin. At this location, a tear fault could take place within the subducting slab to allow overthrusting to the west (collision against the Chinese passive margin) and underthrusting to the north (Lallemand et al., 1997a; Font et al., 1999).

The Ryukyu Arc-trench system trends in a NESW direction east of $126^{\circ} \mathrm{E}$. West of $126^{\circ} \mathrm{E}$, it gradually turns and strikes into an $\mathrm{E}-\mathrm{W}$-trending direction until $123^{\circ} \mathrm{E}$ (Fig. 1). West of $123^{\circ} \mathrm{E}$, less than $200 \mathrm{~km}$ from the collision zone, the trend of the Ryukyu Arc and of the whole forearc system gradually turns northward, reaching a NW-SE azimuth. In this region, the obliquity of the convergence across the Ryukyu Trench increases from $40^{\circ}$, east of $123^{\circ} \mathrm{E}$, to $60^{\circ}$, west of $122^{\circ} 40^{\prime} \mathrm{E}$ (Lallemand and Liu, 1998). A very linear transcurrent fault zone is observed along the rear of the Ryukyu accretionary wedge (and nowhere else), allowing the southern part of the wedge to be dragged laterally toward Taiwan (Dominguez et al., 1998) (Fig. 2). Based on GPS measurements in northeastern Taiwan, in the Ilan plain area (Yu et al., 1997) and on the westernmost Ryukyu islands, including Yonaguni Island (Imanishi et al., 1996), Lallemand and Liu (1998) have compared the horizontal motion of these two segments relatively to the South China block. Owing to the Okinawa Trough extension (Sibuet et al., 1995, 1998), the westernmost Ryukyu Arc segment is presently moving southward, $1.4 \mathrm{~cm} /$ year faster than NE Taiwan. Lallemand and Liu (1998) propose that a $\mathrm{N}-\mathrm{S}$ transform fault zone cutting through the Hoping Basin could accommodate the differential motion between the two blocks (Fig. 2).

Swath bathymetric mapping during the ACT cruise in 1996 revealed a detailed seafloor morphology of the Ryukyu forearc system east of Taiwan (Lallemand et al., 1997b; Liu et al., 1998). The Ryukyu deformation front can now be followed until $122^{\circ} \mathrm{E}$. However, the connection between the northern part of the suture zone onland (northern Longitudinal Valley fault) and the southernmost Ryukyu deformation front (offshore) still remains enigmatic. The sedimentary basins surrounding Taiwan probably record the erosion of the mountain belt since the onset of the orogen. The Ryukyu forearc sedimentary system, however, is singularly located because of its proximity to the collision zone and its vicinity to the northern part of the indentor, the Luzon Arc. The small radius of curvature of the southern Ryukyu Arc probably results from the indentation of the obliquely subducting Luzon Arc (Hsu et al., 1996).

Finally, we aim to study this area sitting at the junction between the subduction and collision of the Philippine Sea plate because various and complex tectonic processes affecting the forearc basins and the Ryukyu Arc have recorded several different tectonic stories among which is the beginning of the collision. Based on the detailed bathymetry map and seismic reflection profiles, we provide a regional overview on the sedimentary structures of the forearc basin region and on the 3D morphology and deformation styles of the Ryukyu Arc (particularly below the forearc basins and at its southernmost extremity). Our purpose is to understand what mechanisms caused the various deformed features and to differentiate whether or not these mechanisms are related to the collision (or pre-collision) environment.

\section{Ryukyu trench-forearc area from recent marine survey}

The southern Ryukyu subduction presents a classical subduction morphostructure including a deep-sea basin subducting at the trench, an accretionary prism, forearc basins, an arc and a back-arc basin (Figs. 1 and 2 ). From south to north, several tectonic units can be distinguished.

The Huatung Basin (earlier named as the West Gagua Basin) constitutes the westernmost oceanic basin of the Philippine Sea plate (Liu et al., 1998). New datings give an Early Cretaceous age for this basin, with a spreading ridge located to the south (Deschamps et al., 2000). The basin is bounded to the south and to the west by the Luzon Arc, to the east by the Gagua Ridge, and to the north by the Ryukyu Trench and accretionary prism (the Yaeyama Ridge). The Gagua Ridge is a $300 \mathrm{~km}$ long, $30 \mathrm{~km}$ wide, $\mathrm{N}-\mathrm{S}$-trending feature that has been described as an ancient fracture zone (Deschamps et al., 1998). The 4-km-high (above sea floor) ridge is actually subducting obliquely beneath the Ryukyu 
Table 1

Seismic data sources

\begin{tabular}{|c|c|c|}
\hline $\begin{array}{l}\text { Ocean Researcher I (ORI } \\
\text { cruises): }\end{array}$ & $\begin{array}{l}\text { 52-56-channel streamer } \\
\text { 4-channel streamer }\end{array}$ & $\begin{array}{l}12 \text { profiles } \\
5 \text { profiles }\end{array}$ \\
\hline $\begin{array}{l}\text { Maurice Ewing (EW9509 } \\
\text { cruise): }\end{array}$ & 160-channel streamer & 5 profiles \\
\hline L'Atalante (ACT cruise): & 6-channel streamer & 23 profiles \\
\hline
\end{tabular}

Margin, indenting the accretionary prism and uplifting the Ryukyu Arc basement below the Nanao forearc basin (Schnurle et al., 1998b; Dominguez et al., 1998). A detailed structural study on the arc-continent collision is presented by Malavieille et al. (2001). In agreement with GPS measurements onland (Yu et al., 1997), the northern segment of the Coastal Range, between $23^{\circ} 40^{\prime} \mathrm{N}$ and $24^{\circ} \mathrm{N}$, is presently accreting to the rest of the island while the southern blocks of the arc are still deforming and rotating. The northern part of the N-S-trending volcanic arc is visible on the surface until $24^{\circ} 05^{\prime} \mathrm{N}$, just south of the Hsincheng Ridge. However, the northern extension of the arc cannot be verified further north from direct observation. The Hsincheng Ridge (Fig. 2) is a deformed sedimentary structure trending in an E-W direction. It could represent a local accretionary prism specific to the Luzon Arc (Font, 1996) or a discarded portion of the Ryukyu accretionary prism (due to dextral N-S transform faulting, Lallemand et al., 1999).

The Ryukyu deformation front is well imaged east of $122^{\circ} \mathrm{E}$. East of the Gagua Ridge, the trench is deeper than $6000 \mathrm{~m}$ and filled with 2-3 s two-way travel time (twt) of sediments (Schnurle et al., 1998b). It shallows to $5500 \mathrm{~m}$, just west of the ridge, and raises to $5000 \mathrm{~m}$ near $122^{\circ} \mathrm{E}$.

The accretionary prism, $50-60 \mathrm{~km}$ wide, is built in front of a backstop that presently corresponds to the southern toe of the Ryukyu Arc. The E-W-trending wedge, east of the Gagua Ridge, turns to a WNWESE direction and becomes shallower (3000-3500 m) west of the ridge. Due to the obliquity of the subduction, transcurrent faulting affects the rear of the prism, dragging the wedge toward Taiwan (Lallemand et al., 1999). A single major right-lateral fault, the Yaeyama fault zone, well imaged on bathymetry, is trending N95 ${ }^{\circ}$ east of the Gagua Ridge (Fig. 2). At about $123^{\circ} \mathrm{E}$, the trend turns toward the north, reaching $\mathrm{N} 320^{\circ}$ in azimuth, and its morphological expression disappears southeast of the Nanao forearc basin. West of $122^{\circ} 40^{\prime} \mathrm{E}$, another segment of the transcurrent fault zone, the West Yaeyama fault zone, striking N288 ${ }^{\circ}$, is clearly visible. At $122^{\circ} 15^{\prime} \mathrm{E}$, the fault direction suddenly changes to trend along a $\mathrm{N} 313^{\circ}$ azimuth, close to the convergence vector $\left(\mathrm{N} 306^{\circ}\right.$ after $\mathrm{Yu}$ et al., 1997). The right-lateral strike-slip fault seems to extend through the Hsincheng Ridge (Fig. 2).

The forearc region in the studied area consists of 3 forearc basins shallowing westward (Lallemand et al., 1999). From east to west, they are the East Nanao Basin, the Nanao Basin and the Hoping Basin (Fig. 2).

The Ryukyu Arc is a drifted fragment of continental crust due to the opening of the Okinawa Trough. The southern Ryukyu Arc is non-volcanic. Present arc volcanism occurs either along the axis of the southern Okinawa Trough, or on its southern edge (Sibuet et al., 1987). The steep slope of the arc is marked by a regional bayonet shape wall (Fig. 2). These bayonet segments could represent $\mathrm{N}-\mathrm{S}$ to NW-SE strike-slip fault with right-laterally offset (Hsu et al., 1996).

The very steep slope, west of the Hoping Basin, is affected by numerous small canyons merging into a single one, named Hoping canyon by Liu et al. (1998). Eroding the Hoping Basin (U shape on seismic profiles), this canyon supplies the Nanao Basin with turbidites (Lallemand et al., 1997a).

\section{Forearc basement mapping}

Since 1995, several surveys have been conducted offshore eastern Taiwan. The 1995 TAICRUST cruise, onboard R/V Maurice Ewing, collected 4 multichannel seismic reflection profiles (refraction studies have been done on three of them) in the study area. Several seismic cruises carried out by the R/V Ocean Researcher I, in addition to L'Atalante cruise in 1996, provide a dense coverage of the seismic reflection profiles in the region (see Table 1). Overall, they are more than 45 seismic reflection profiles available in the westernmost portion of the Ryukyu Trench-forearc region (Fig. 3). These reflection seismic profiles have been used to construct the morphology of the arc basement. In this section, we describe the techniques used to image the Ryukyu Arc 


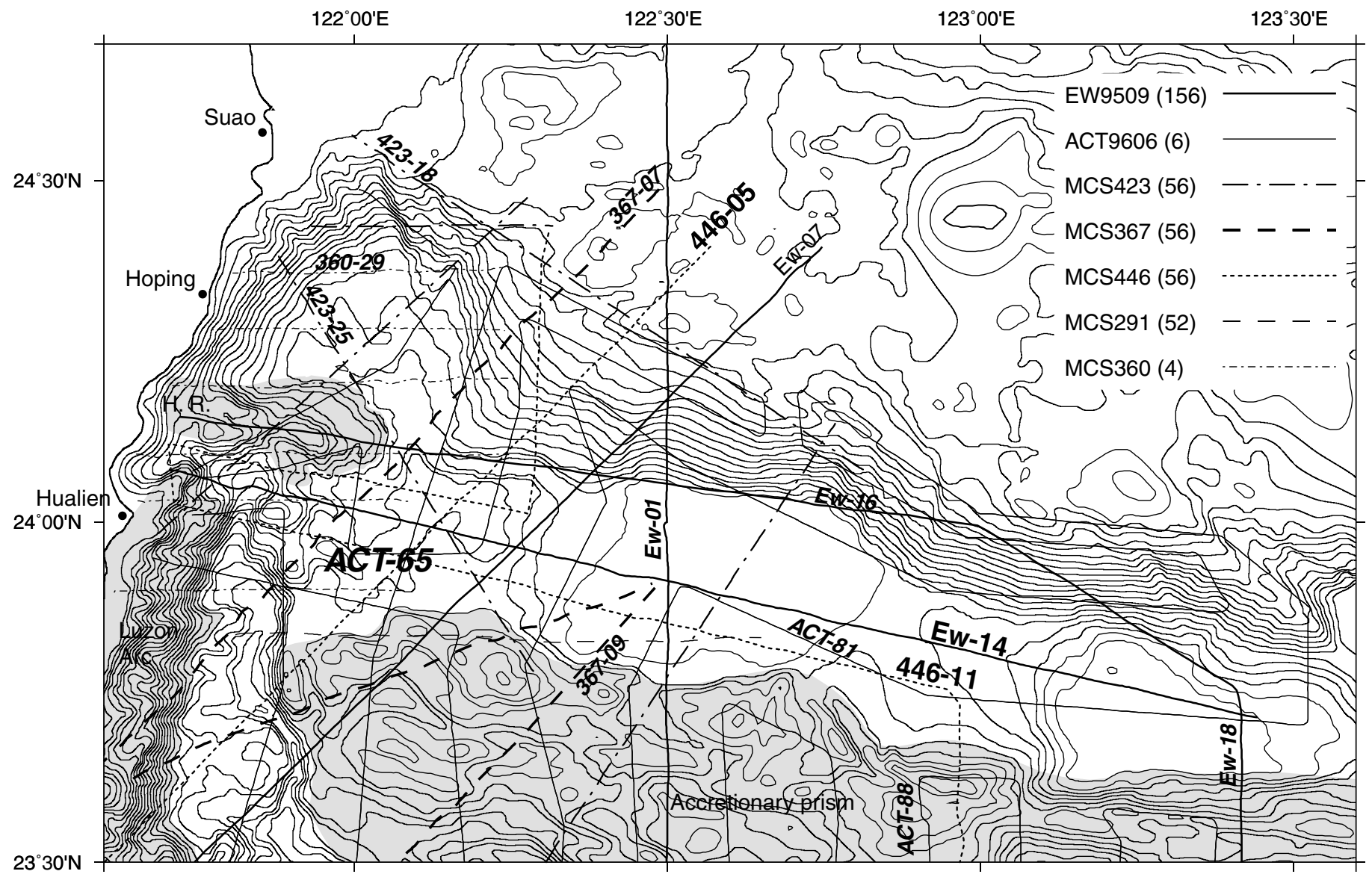

Fig. 3. Location map of the seismic reflection profiles interpreted in this study. Shaded areas are the Hsincheng Ridge (HR), the Luzon Arc and the accretionary prism. The oblique text illustrate the seismic profiles showed in Table 2. 
Table 2

Seismic data sources

\begin{tabular}{|c|c|c|c|c|}
\hline Research vessel & Year & Cruise-line & Channel number & References \\
\hline \multicolumn{5}{|c|}{ Ocean Researcher I } \\
\hline & 1993 & $360-29$ & 4 & \multirow[t]{4}{*}{ Lallemand et al. (1997a) } \\
\hline & 1993 & $367-07$ & 56 & \\
\hline & 1995 & $423-18$ & 52 & \\
\hline & 1995 & $423-25$ & 52 & \\
\hline & 1993 & 367-09 & 56 & Lallemand et al. (1999) \\
\hline & 1996 & 446-05 & 48 & \multirow[t]{2}{*}{ This study } \\
\hline & 1996 & $446-11$ & 48 & \\
\hline \multicolumn{5}{|l|}{ Maurice Ewing } \\
\hline & 1995 & 9509-01 & 160 (southern part) & \multirow[t]{3}{*}{ Schnurle et al. (1998b) } \\
\hline & 1995 & $9509-14$ & 160 (eastern part) & \\
\hline & 1995 & $9509-18$ & 160 & \\
\hline & 1995 & $9509-14$ & 160 (total) & This study \\
\hline \multicolumn{5}{|l|}{ L'Atalante } \\
\hline & 1996 & act-65 & 6 & Lallemand et al. (1999) \\
\hline & 1996 & act-81 & 6 & \multirow[t]{2}{*}{ Lallemand et al. (1999) and Dominguez et al. (1998) } \\
\hline & 1996 & act-92 & 6 & \\
\hline & 1996 & act- 88 & 6 & Dominguez et al. (1998) \\
\hline
\end{tabular}

basement and the major results derived from this study.

\subsection{Seismic data}

The seismic data were processed at the Institute of Oceanography, National Taiwan University using both Sioseis and ProMAX seismic processing softwares on two SUN SPARC20 work stations. Details about seismic sources, navigation and data processing sequences are the same, or very similar, than those presented in Schnurle et al. (1998a,b).

The 45 seismic profiles run through the study area in various directions (Fig. 3): 11 profiles run from E-W to NW-SE direction, 8 profiles from NW-SE to $\mathrm{N}-\mathrm{S}, 13$ profiles from $\mathrm{N}-\mathrm{S}$ to $\mathrm{NE}-\mathrm{SW}, 13$ profiles from NE-SW to E-W, thus providing a good coverage for basement mapping.

\subsection{Main observations}

The interpretation of all the seismic reflection profiles leads us to pinpoint a few key reflections, namely the East Nanao, Nanao, Hoping and Suao Basin basement reflections and, particularly, the top of the Ryukyu Arc reflection. Only a few examples of profiles are presented in this section. The reader may also refer to other studies (Table 2) to see additional seismic lines.

\subsubsection{Line Ewing-14 (Ew-14)}

Because the Ew-14 profile is $200 \mathrm{~km}$ long, Fig. $4 \mathrm{a}-\mathrm{c}$ present this $\mathrm{E}-\mathrm{W}$-trending line in 3 different segments. The location of each section is marked on the individual location map enclosed in each figure. Note that the sections overlap each other about $10-20 \mathrm{~km}$.

The seismic profile runs across three forearc basins. The easternmost one is the East Nanao Basin (centered at $23^{\circ} 40^{\prime} \mathrm{N}-123^{\circ} 20^{\prime} \mathrm{E}$ ) and is located $130 \mathrm{~km}$ away from the island of Taiwan. It is the deepest $(4600 \mathrm{~m})$ and the smallest $(20 \mathrm{~km}$ wide and $50 \mathrm{~km}$ long) one of the three basins (Fig. 4a).

The Nanao Basin is separated from the East Nanao Basin by the Nanao rise (Schnurle et al., 1998b). This rise shallows to $3500 \mathrm{~m}$ in water depth and is very well aligned with the Gagua Ridge axis. The reflection of the basement corresponds to the top of the Ryukyu Arc. The top of the dome-like basement bulge can be 
(a)

W

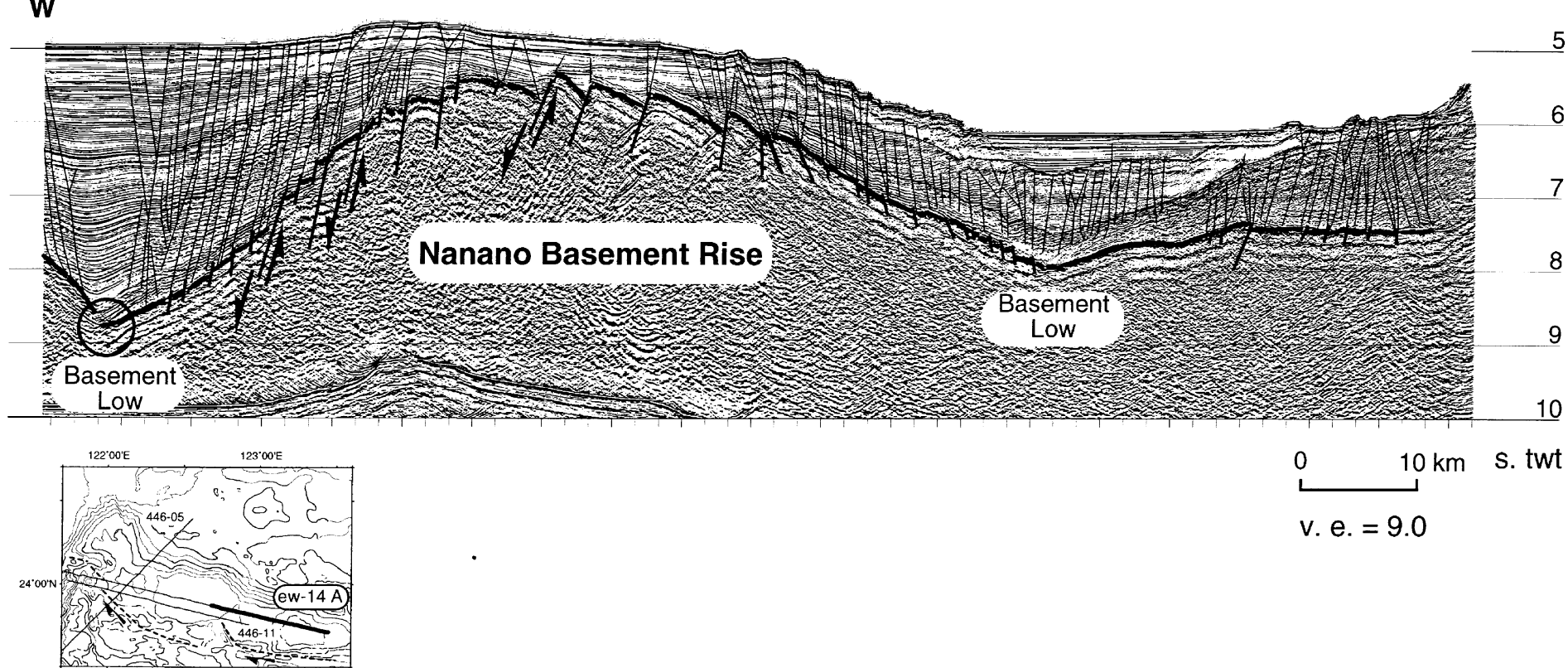

Fig. 4. (a) Migrated seismic reflection profile and its interpretation showing the eastern portion of the Ew-14. Location of this section is shown as thick line in the location map. The dashed line on the location map represents the transcurrent fault zone (see text). v.e. = vertical exaggeration; s. twt. = two way travel time in seconds. Modified after Schnurle et al. (1998b). (b) Migrated seismic reflection profile and its interpretation showing the central portion of the Ew-14. Location of this section is shown as thick line in the location map. The dashed line on the location map represents the transcurrent fault zone (see text). v.e. = vertical exaggeration; s. twt. = two-way travel time in seconds. Modified after Schnurle et al. (1998b). (c) Migrated seismic reflection profile and its interpretation showing the western portion of the Ew-14. Location of this section is shown as thick line in the location map. The dashed line on the location map represents the transcurrent fault zone (see text). Note that below and east of the transcurrent fault, the top of the Ryukyu Arc basement is no longer visible. v.e. $=$ vertical exaggeration; s. twt. $=$ two way travel time in seconds. 

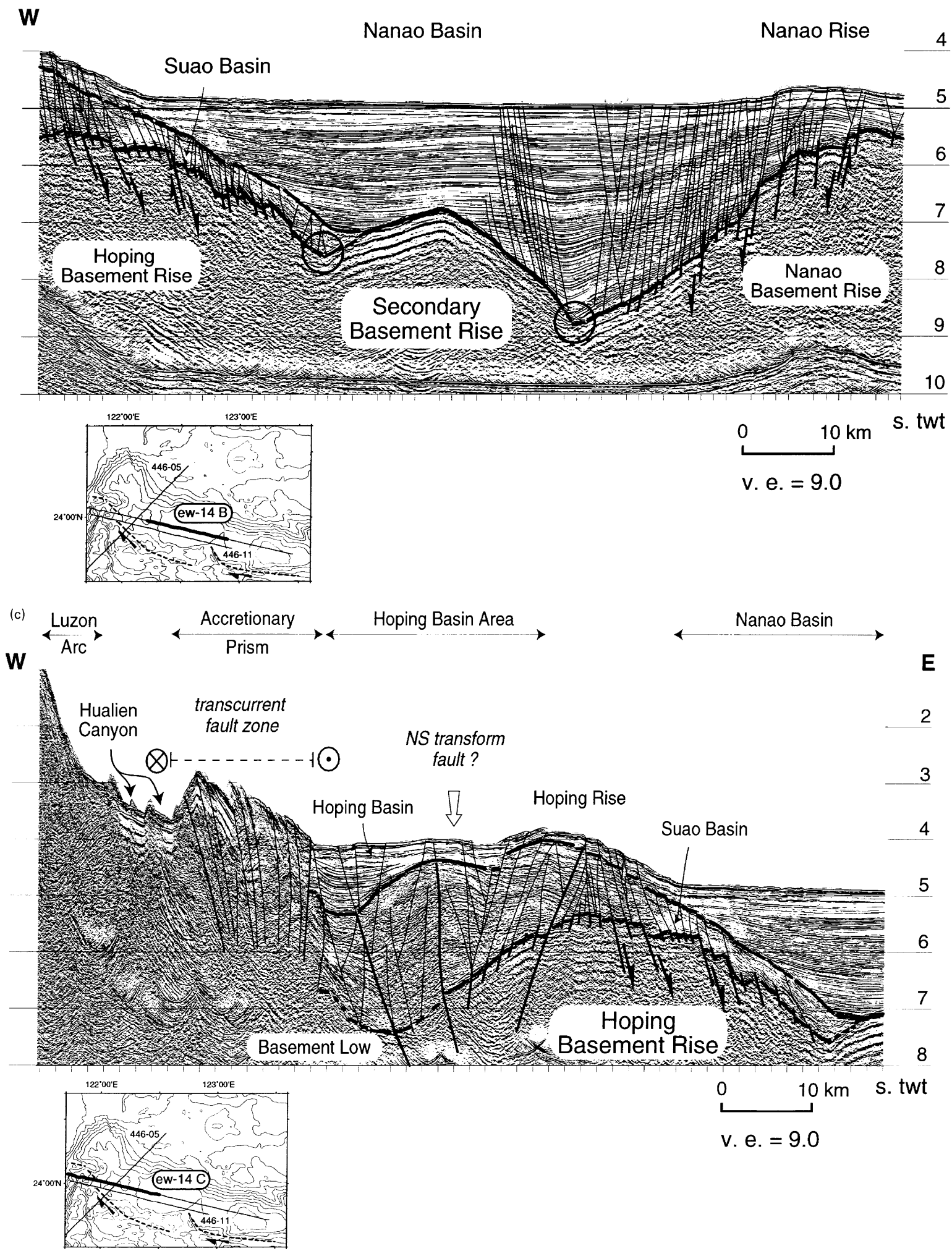

Fig. 4. (continued) 
followed for about $30 \mathrm{~km}$ at $5.5 \mathrm{~s}$ twt and is covered by $0.7 \mathrm{~s}$ twt of recent sediments (Fig. $4 \mathrm{a}$ ). Both flanks of the basement high are affected by normal faults, eastward dipping on the eastern side and westward dipping on the western side. These faults cut sharply through basement and sediments. Schnurle et al. (1998a) conclude from their observations that the Nanao basement rise was formed due to the oblique subduction of the Gagua Ridge. The uplift of the forearc basement is syn-sedimentary, and the western part of the Nanao rise is still active. Interestingly, the E-W trending Yaeyama fault, which lies south of the East Nanao Basin and the Nanao basement rise, turns northwestward once it passes over the subducted part of the Gagua Ridge. According to Dominguez et al. (1998) and Lallemand et al. (1999), the change in strike of the Yaeyama fault is not due to the subducting Gagua Ridge, but predates the ridge subduction.

West of the Nanao rise, the $30-\mathrm{km}$-wide and $60-\mathrm{km}$ long Nanao Basin is $3700 \mathrm{~m}$ deep. Centered at $23^{\circ} 50^{\prime} \mathrm{N}-122^{\circ} 30^{\prime} \mathrm{E}$, it follows a WNW-ESE azimuth. The Nanao Basin comprises two basement lows that are separated by a small 'peak-like' basement high culminating at $6.5 \mathrm{~s}$ twt (Fig. 4b). The sediment of the Nanao Basin are represented by turbidites coming from the Hoping canyon. The reflections are flat, parallel and continuous. Both flanks of the small basement high are not deformed, as most of the Nanao Basin sediments laying on top of it. An east-dipping sedimentary layer, buried below Nanao Basin sediments and about $0.5 \mathrm{~s}$ twt thick, ends at the westernmost tip of the rise flank. This layer is interpreted to be the easternmost termination of the Suao Basin strata (see next paragraph).

Fig. 4c reveals the westernmost basement high, named the Hoping basement rise. The Hoping basement rise is located directly beneath a 3100-m-deep topographic bulge, namely the Hoping rise. The top of the rise reaches $5.5 \mathrm{~s} \mathrm{twt}$ and is nearly flat for about $20 \mathrm{~km}$. Similar to the Nanao rise, both flanks of the Hoping rise are affected by normal faults. Its western flank extends to a depth of about $7.5 \mathrm{~s}$ twt on the seismic section.

West of the Hoping rise, the forearc basin is actually composed of two superimposed basins (Lallemand et al., 1997a): the younger Hoping Basin lies on top of the Suao Basin (Fig. 4c). The Suao Basin, with a sedimentary pile over $3 \mathrm{~km}$ thick, under- went a spectacular subsidence of $3 \mathrm{~km}$ on its southwestern side (Lallemand et al., 1997a). On its southern edge, the basin ends abruptly against a shear zone that affects the accretionary prism. The Suao Basin strata conformably overlie the Hoping basement rise.

The N-S-trending, 3000-m-deep, Hoping Basin strata unconformably overlie the Suao Basin strata. Thickness of the Hoping Basin reaches $1.8 \mathrm{~s}$ twt at its deepest part. The sediments in the southwestern part of the basin are deformed and incorporated into the accretionary wedge or into what could be the basement of the Hsincheng Ridge. In the northern part, the sediments are undeformed and probably originated from ancient levees. Several canyons are presently eroding recent sediments, suggesting that the Hoping Basin is no longer filling (Lallemand et al., 1997a).

On the E-W section (Fig. 4c), reflections of the Hoping Basin display a few onlaps against the top of the Suao Basin strata in its eastern part. The faults that cut through the western flank of the Hoping basement rise and affect both the Suao and Hoping sediments are organized into a complex flower structure. This structure could be associated to a NS-trending en échelon transform fault zone described by Lallemand and Liu (1998). West of the Hoping Basin, Ew-14 runs across the West Yaeyama fault zone (see location map in Fig. 4c). Below and west of this shear zone, the reflection corresponding to the top of the Ryukyu Arc basement is no longer visible.

\subsubsection{Line 446-11 (ORI)}

The seismic line 446-11 (Fig. 5) runs parallel to Ew-14 and lies about $7 \mathrm{~km}$ south of it. These two profiles present similar structures of the basement. The top of the Ryukyu Arc basement follows the same 'highs' and 'lows' distribution. However, SE of the Nanao Basin, at the location where the transcurrent fault ends, the basement reflection suddenly 'disappears' on line 446-11. Instead, a deformed area of incoherent reflections takes place without disturbing the shallow sediments. Another E-W seismic section located between the Ew-14 and 446-11 profiles, line ACT-81 (Fig. 3; Dominguez et al., 1998) presents the same feature. In both sections, the deformed basement does not affect the seafloor sediment. 


\subsubsection{Line 446-05 (ORI)}

The NE-SW-trending line 446-05 cuts the forearc system across the Hoping basement rise. It crosses successively, from south to north, the Luzon Arc, the Hualien Canyon that runs at the foot of the Ryukyu accretionary prism, the Hoping Basin and the southern slope of the Ryukyu Arc (Fig. 6a). The profile cuts perpendicularly across the transcurrent fault (see location map in Fig. 6a). The top of the subducting Philippine Sea plate is observed down to $8 \mathrm{~s}$ twt below the accretionary prism. The Ryukyu Arc reflection can be nicely followed from the southern slope of the arc (where $1 \mathrm{~s}$ twt of sediments of the Suao Basin covers it) until it reaches the southern side of the Hoping basement rise.

Enlarged seismic section (Fig. 6b) reveals that the basement reflection disappears near the transcurrent fault zone. This observation is common to all the lines perpendicular to the trench. One may think that diffractions originate from the fault zone and thus mask the basement reflection. However, the N-S transform fault that cuts through the Ryukyu Arc basement and the sediment below the Hoping Basin (Fig. 4c), does not generate any diffraction. The top of basement is perfectly visible there. In any case, despite the fact that the fault zone might 'hide' the basement, the top of the basement reflection is never visible south of the shear zone.

Line 446-05 shows that the top of the Ryukyu Arc basement is probably offset by a steeply southward-dipping normal fault with a throw of about $0.8 \mathrm{~s}$ twt below the 500-m-deep Hoping canyon. The same feature is observed on profile Ew-07 located to the east of this profile (see Fig. 6). This normal fault is no longer visible west of line 446-05.

\subsection{Basement mapping and time-depth conversion}

Coverage of the seismic profiles in the study area is dense enough to map the different tectonic units of the area. Key reflections along the bottom of the East Nanao, Nanao, Hoping and Suao Basins have been digitized. The top of the Ryukyu Arc basement reflection has been identified also. Crossover errors of these digitized reflections never exceed $0.05 \mathrm{~s}$ twt. Fig. 7a presents a contour map of the top of the Ryukyu Arc basement in twt (seconds) below sea level.

To convert the sedimentary thickness from time to depth, detailed velocity analyses are performed along seismic profile Ew-14 (Figs. 3 and 4). Velocity functions are determined at every $500 \mathrm{CDP}$ (every $6 \mathrm{~km}$ ). About 30 velocity functions were derived across the whole Ew-14 profile. Deformation of the forearc sediments does not seem to modify significantly the velocity functions at different locations. As a matter of facts, the interval velocities are mainly dependent on the compaction of the sediments (i.e. the depth of burial). We therefore combined our velocity functions into a single velocity profile representing the sedimentary velocity of the region (Fig. 7b). This velocity function is then used uniformly for time to depth conversion of the sedimentary units covering the Ryukyu Arc basement.

An estimation of the accuracy of this conversion is obtained by comparing the time to depth conversions performed at the 30 locations where velocity analyses were performed with their respective velocity functions, and the depth obtained with the average velocity profile. We estimate the precision of this conversion to be within 5\% of the proposed depths. Furthermore, our estimated basement depths are in good agreement with the results of refraction studies (McIntosh and Nakamura, 1998; Wang and Chiang, 1998). Fig. 8 shows the depth of Ryukyu Arc basement below sea level.

\section{Morphostructure of the forearc system}

Fig. 8 provides morphostructural insights of the westernmost Ryukyu forearc region. In the following section, the main aspects are presented from north to south.

\subsection{Southern Ryukyu Arc: highly dipping slope and bayonet shape}

To the north, the southern flank of the Ryukyu Arc is represented by a slope dipping southward with an angle varying from $11.5^{\circ}$ near the western end of the arc to $9.5^{\circ}$ north of the Nanao and East Nanao Basins. As clearly imaged on the bathymetry map, this slope (Fig. 9, upper solid line) is marked by a bayonet shape composed of two main segments along which the eastern part of the arc is offset toward the south (Figs. 2 and 9). The eastern segment, near $122^{\circ} 45^{\prime} \mathrm{E}$, strikes $\mathrm{N} 310^{\circ}$. There, the western block of the arc is 


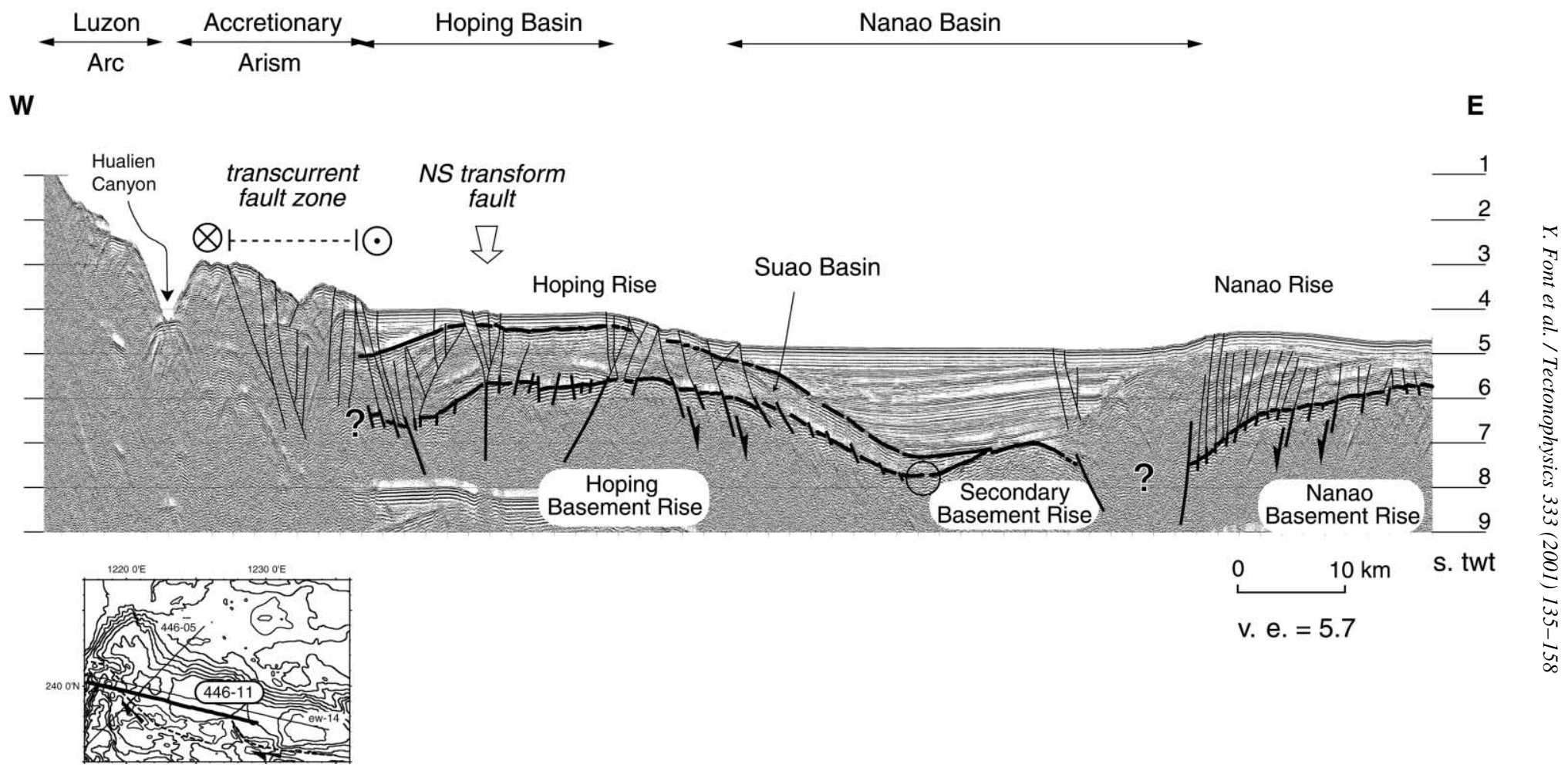

Fig. 5. Migrated seismic reflection profile 446-11 and its interpretation. Location of this section is shown as thick line in the location map. The dashed line on the location map represents the transcurrent fault zone (see text). Note that below and east of the transcurrent fault, the top of the Ryukyu Arc basement is no longer visible. v.e. $=$ vertical exaggeration; s. twt. $=$ two-way travel time in seconds. 
shifted $15 \mathrm{~km}$ further north than the eastern block. Note that the strike of the bayonet is intriguingly parallel to the strike of the Yaeyama fault that lies about $50 \mathrm{~km}$ to the south (Fig. 9, lower solid line). The maximum offset $(35 \mathrm{~km})$ is observed on the western segment, at $122^{\circ} 15^{\prime} \mathrm{E}$. At this longitude, the strike of the West Yaeyama fault zone does not parallel that of the arc slope.

\subsection{Forearc basins: morphological highs and lows}

Below the forearc basins, the geometry of the Ryukyu basement is quite different. It is composed of morphologic highs and lows. Fig. 10 shows a true scale cross-section along seismic profile Ew-14 (Fig. 4a-c) that illustrates this geometry. The two major basement highs (Hoping and Nanao basement rises) are affected by normal faults, while the secondary basement high within the Nanao Basin is not deformed.

The Nanao basement rise is asymmetrical with its eastern flank dipping $4^{\circ}$ and its western one dipping $12.5^{\circ}$. The top of the rise is about $4.2 \mathrm{~km}$ below sea level, covered by $500 \mathrm{~m}$ of young and faulted sediments.

The Hoping basement high culminates at $4.8 \mathrm{~km}$ below sea level. The eastern flank of the basement rise, with a dipping angle of about $7.5^{\circ}$, displays normal faults that also affect the Suao Basin strata, but only few of them cut through the younger Nanao Basin sediments. The deformation of the western flank, which dips $10^{\circ}$, is represented by normal and apparently reverse faults that formed a flower structure. The Suao Basin strata lie conformably over the forearc basement while the Hoping Basin strata lie unconformably above the Suao Basin strata.

The secondary undeformed basement high is also asymmetrical with a steeper dipping flank on the east $\left(10^{\circ}\right)$ and a gentle dipping flank on the west $\left(3^{\circ}\right)$. The overlying Nanao sediments are not deformed.

The depth of the basement lows increases westward from 7 to $10.5 \mathrm{~km}$, whereas the depth of the basin floor decreases westward (Figs. 8 and 9). The deepest part of the forearc basin is located at the eastern tip of the Hsincheng Ridge and is filled by more than $7.5 \mathrm{~km}$ of sediments $(1.5 \mathrm{~km}$ corresponding to the Hoping Basin and more than $6 \mathrm{~km}$ for the Suao Basin).

The transition from the steeply dipping arc slope along the southern flank of the Ryukyu Arc to the 'lows-and-highs' morphology below the forearc basins is not uniform. Seismic profile 446-05 (Fig. 6) seems to suggest the existence of an E-W trending, southward dipping, normal fault that offsets the southern slope of the Ryukyu Arc from about 400 to $800 \mathrm{~m}$ from the Hoping rise. Elsewhere, the transition seems to be continuous and no other major $\mathrm{E}-\mathrm{W}$ trending normal fault has been observed. The reflections of the Suao Basin strata lying on top of the Ryukyu Arc slope are usually clearly imaged (e.g. Lallemand et al., 1997a, line 367-07). However, above the E-W trending normal fault, the reflections of the Suao Basin strata are unclear and hardly observed. We can then admit that the Suao Basin is affected by the fault (Fig. 6b).

\subsection{Southernmost termination of the backstop}

The Ryukyu Arc basement reflection is visible on most of the seismic sections in the forearc basins until they cross the transcurrent fault zone located along the northern edge of the accretionary prism. South of the transcurrent fault zone, the Ryukyu Arc reflection is never observed. This remark is true when the surface of the sea floor is flat enough to allow the observation of the main reflection (that is to say on the western part of the West Yaeyama fault). As soon as the backstop is buried below the highly deformed and thick accretionary prism, the trace of the reflection becomes less clear.

Two seismic sections, running slightly north of the morphological termination of the Yaeyama fault zone, show a clear discontinuity in the basement reflection (e.g. western flank of the Nanao rise, Fig. 5). The basement reflection cannot be observed SE of this location. About $5 \mathrm{~km}$ to the north (Fig. 4b), the reflection is again perfectly continuous. Note that this step of the basement between the Yaeyama and the West Yaeyama fault zone coincides with the morphological basement low located just west of the Nanao basement rise (Fig. 8).

\section{Discussion}

\subsection{Structural significance of the basement highs and lows}

The top of the southernmost Ryukyu Arc shows two 
(a)
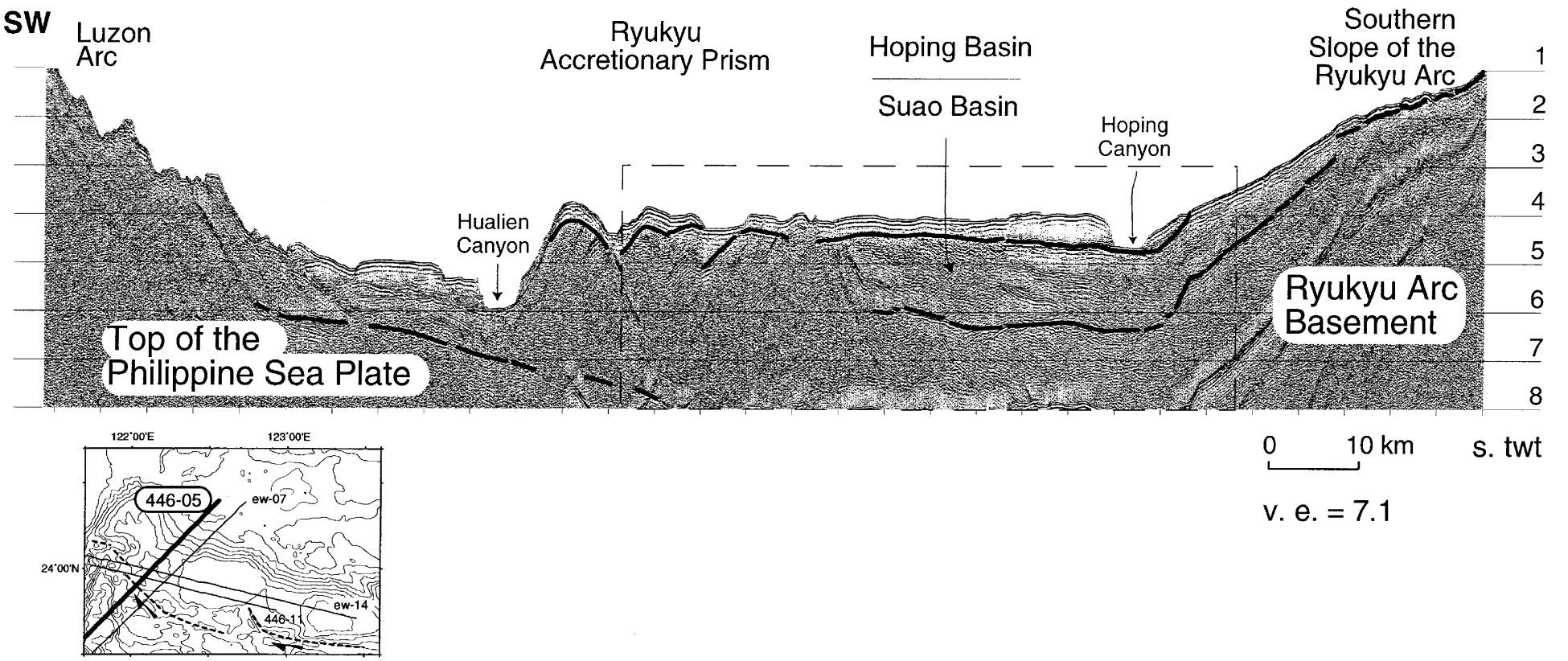

$0 \quad 10 \mathrm{~km} \quad$ s. twt

v. e. $=7.1$

Fig. 6. (a) Migrated seismic reflection profile 446-05 and its interpretation. Location of this section is shown as thick line in the location map. The dashed line on the location map represents the transcurrent fault zone (see text). The section blocked by dashed lines is shown in (b) to reveal details of the seismic image. v.e. $=$ vertical exaggeration; s. twt. $=$ two-way travel time in seconds. (b) Enlarged seismic image of the enclosed section showed in (a). Note that below and south-east of the transcurrent fault, the top of the Ryukyu Arc basement is no longer visible. 
(b)

Fig. 6. (continued)

very distinct shapes represented, on one side, by the steeply dipping plane of the Ryukyu Arc southern slope, and, on the other side, by the highs-and-lows morphology which characterize the toe of the backstop below the forearc basins (Fig. 8). The two morphological modes are separated locally by a 800-m-throw normal fault, but the transition seems elsewhere continuous. This leads one to think that the geometry of the southern part of the studied area is not the original one, but has been shaped by regional tectonics. Initial observation of the forearc basement highs and lows in this convergent context could easily be interpreted as compressional folds. However, except below the Hoping Basin where a few apparent reverse faults are observed, the whole forearc region is dominated by normal faults. Thus, the basement highs and lows do not seem to be the results of compressional forces.

The Nanao basement rise (Fig. 4a) has already been described as an uplifted area caused by the oblique subduction of the Gagua Ridge below the Ryukyu Margin. The Hoping basement rise (Fig. 4c) displays several similarities with the Nanao basement rise, such as the flat-top affected by eastward-dipping normal faults, dimension of the bulges, normal faults cutting through the flanks of the rise and dipping in the same direction as the flank itself, and surface bump delimited just above the basement high. These similarities suggest that the Hoping high was probably formed by similar mechanisms as that of the Nanao high. The Hoping basement rise could thus be uplifted due to the subduction or the underplating of some 

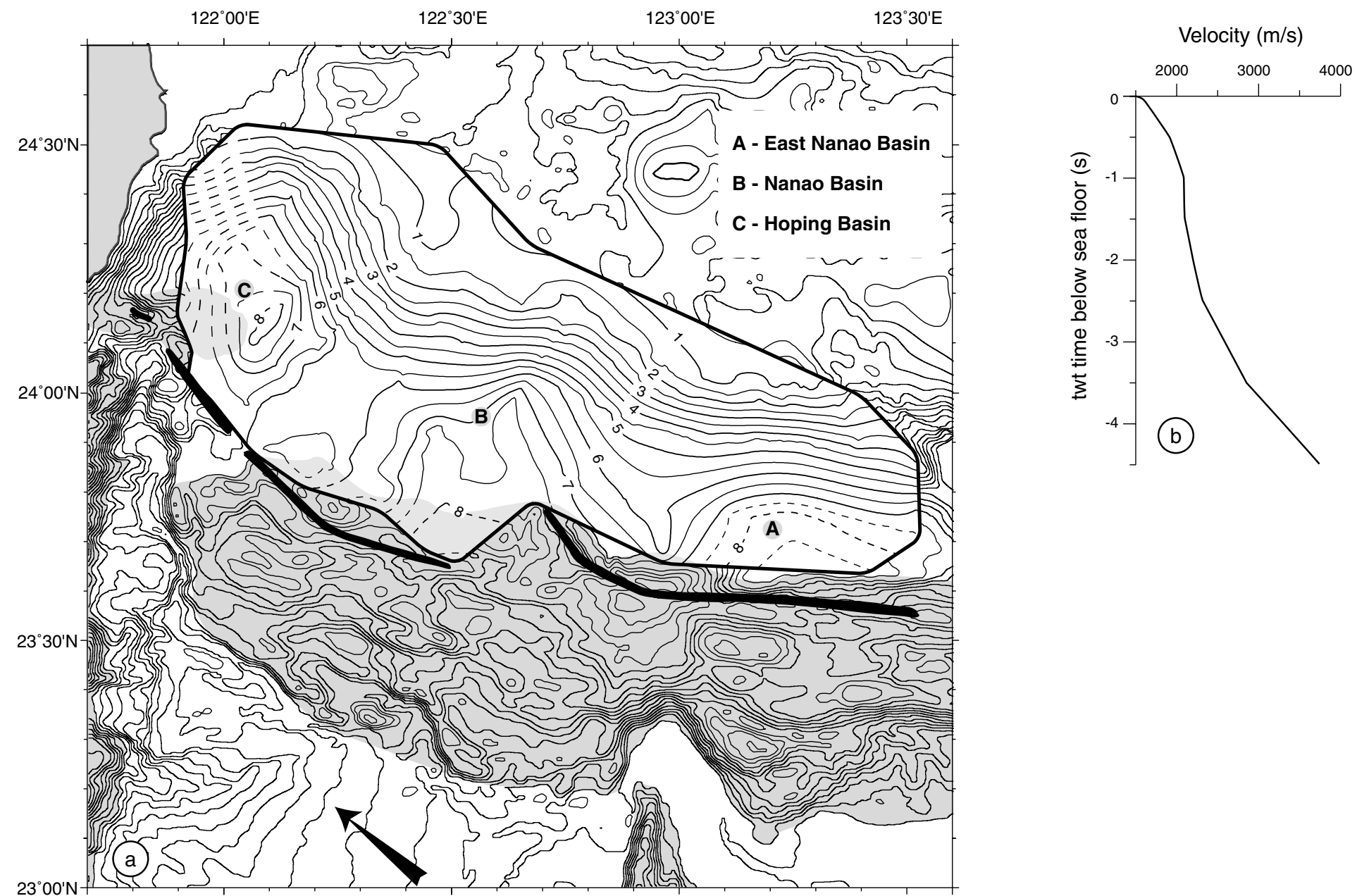

Fig. 7. (a) Map showing the top of Ryukyu Arc below sea level in two-way travel time (s). Black bold line circles the area where the Ryukyu basement reflection is observed on seismic section. Contour line (in $500 \mathrm{~ms}$ interval) within this enclosed area shows depth of the Ryukyu basement reflection in twt below sea level. Dashed contour lines indicate where the Ryukyu Arc reflection is less clear. The black arrow represents the convergent direction after Yu et al., 1997. The contour interval of the bathymetry map (outside of the circled area) is $200 \mathrm{~m}$. Shaded areas are submarine ridges (see Figs. 2 and 3 for details). (b) Velocity function applied to the forearc basin sediments to convert their thickness from twt to kilometer. 


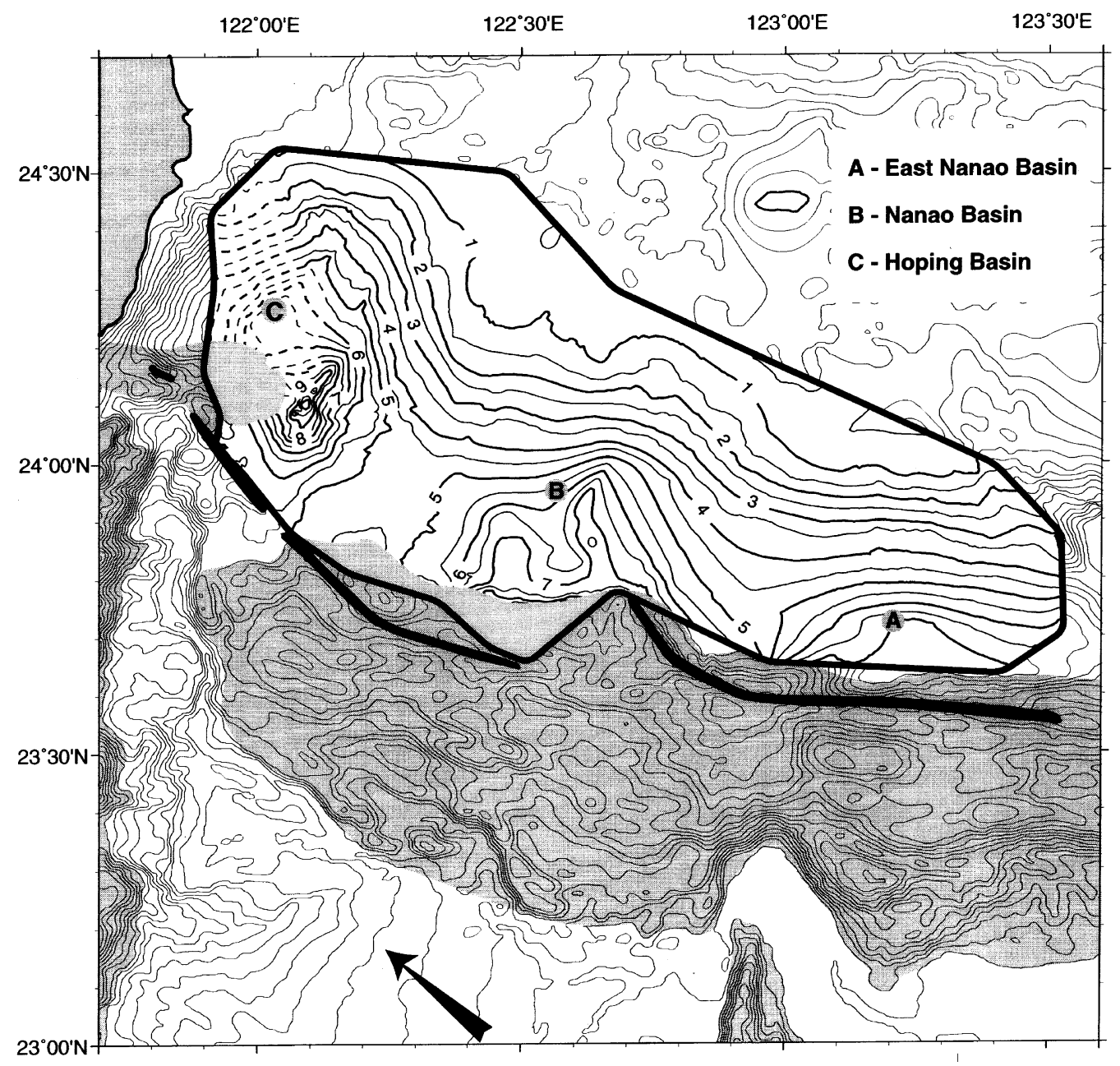

Fig. 8. Map showing the depth (in km) of the Ryukyu Arc basement below sea level after time to depth conversion. Depth contours inside the enclosed area are in 500-m intervals. Other symbols are the same as in Fig. 7.

local oceanic asperity. The nature of this asperity is still enigmatic. It could be represented by a high feature subducted with the Philippine Sea plate (e.g. seamount). Another close candidate could be the colliding Luzon Arc. A N-S refraction transect crossing just west of the raised region suggests that the P-wave velocities of the region are similar to those of the Coastal Range, i.e. the volcanic Luzon Arc (Cheng et al., 1996). However, because the data corresponds to a neighboring area and not the bump itself, it is sensible to conclude directly that the asperity causing the uplift belongs to the Luzon Arc. Even if the asperity does correspond to Luzon Arc material, because the uplifted area is fairly well delimited, on the surface as well as in depth, this material has to be detached from the previous arc, and so decoupled from the Philippine Sea plate.

\subsection{Relative chronology of tectonic events in the Hoping area}

Even though the Hoping Basin area is crucial to the understanding of early stage of Taiwan arc-continent collision, no sedimentation data and age constraints have been acquired. A relative chronology has been established for this area by Lallemand et al. (1997a). 


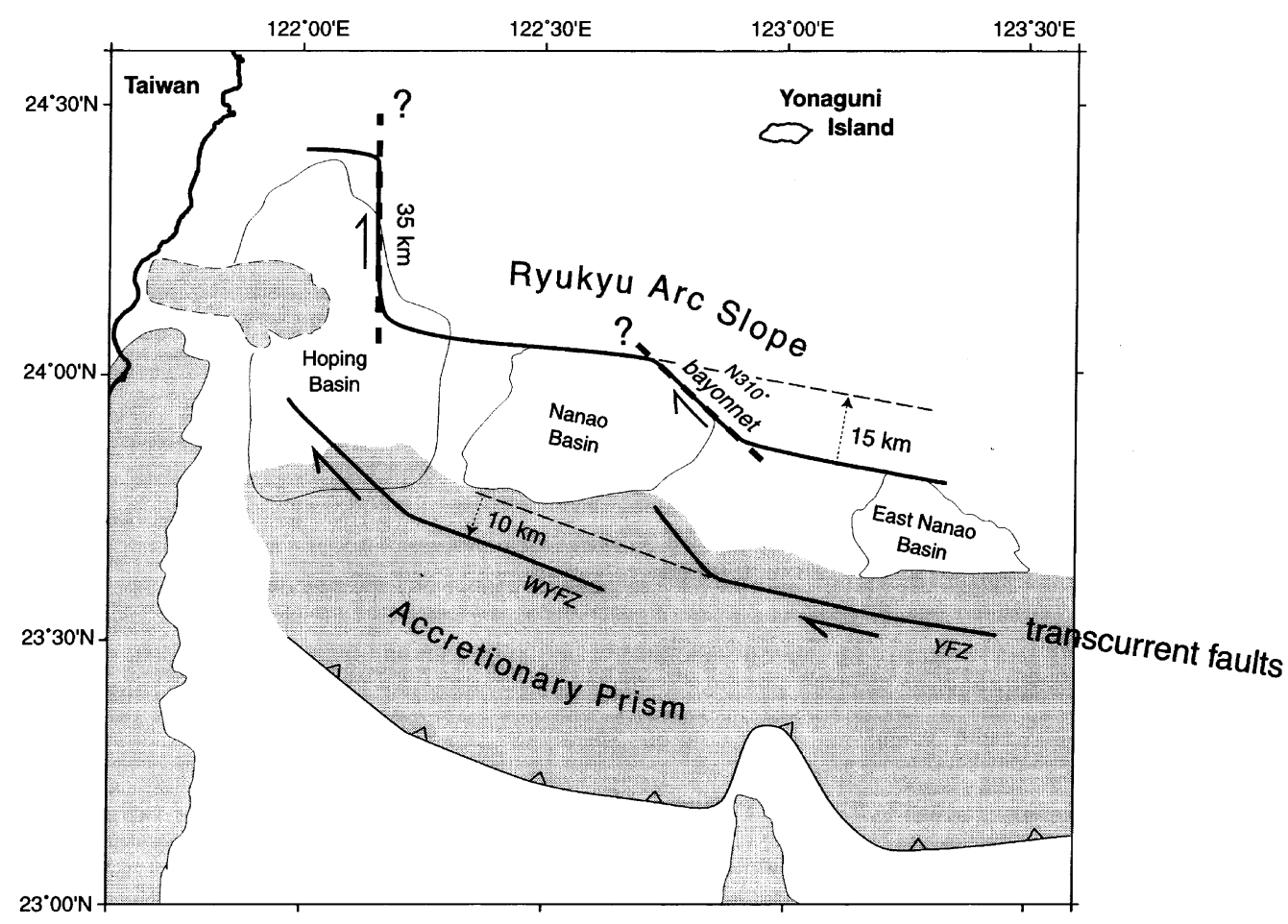

Fig. 9. Diagram mapping the structural feature based on bathymetry map. The schema illustrates the two main bayonets located on the southern slope of the Ryukyu Arc to the north (upper solid line), and the transcurrent fault zone to the south (lower solid line). Bold dashed line represent possible right-lateral strike-slip faults. Shaded areas represent the Hsincheng Ridge, the Luzon Arc and the accretionary prism (Ac. P.). Note that: (1) the parallelism between the western bayonet and the Yaeyama fault zone (YFZ); (2) the western bayonet is located exactly north of the YFZ; and (3) west of the western bayonet, the slope of the arc is shifted $15 \mathrm{~km}$ northward, while west of the YFZ, the West Yaeyama fault zone (WYFZ) is shifted $10 \mathrm{~km}$ southward.

This paper supplies additional chronological events to complement prior studies.

The Suao Basin strata underwent a drastic subsidence of more than $3 \mathrm{~km}$ on its southwestern part. Until now, the only hypothesis proposed to explain this subsidence is a nearly vertical fault tearing subducting the Philippine Sea plate (Lallemand et al., 1997a). Because the reflections of the Suao Basin strata conformably overlay the Hoping basement high, the Hoping uplift occurred after the deposition of Suao Basin sediments. The tectonic uplift event probably caused the second deformation stage of the Suao Basin (the first one being the subsidence; the third one being the $\mathrm{N}-\mathrm{S}$ transform fault zone, Lallemand et al., 1997a).

The Hoping Basin strata unconformably overlay the deformed Suao Basin. This unconformity attests for a lack of sedimentation. Several hypotheses could explain this deposition hiatus. If we consider that the Taiwan orogen had already started when the Suao Basin was formed (that is to say, if the sediments of the Suao Basin derived from Taiwan mountain belt erosion), the non-deposition period could be attributable to a drastic environmental change (climatic or eustatic) or to a tectonic event (such as a slowing down in the Taiwan orogen that reduce the erosion rate). If we consider that the Taiwan orogen started after the Suao Basin sedimentation, the 'lack' of sedimentation would correspond to the depositional onset of the product of the Taiwan erosion. Until now, we have no data to support one or the other explanation.

The few onlaps of the Hoping Basin sediment reflections on top of the Suao Basin strata (above the Hoping basement rise) suggest that the Hoping 

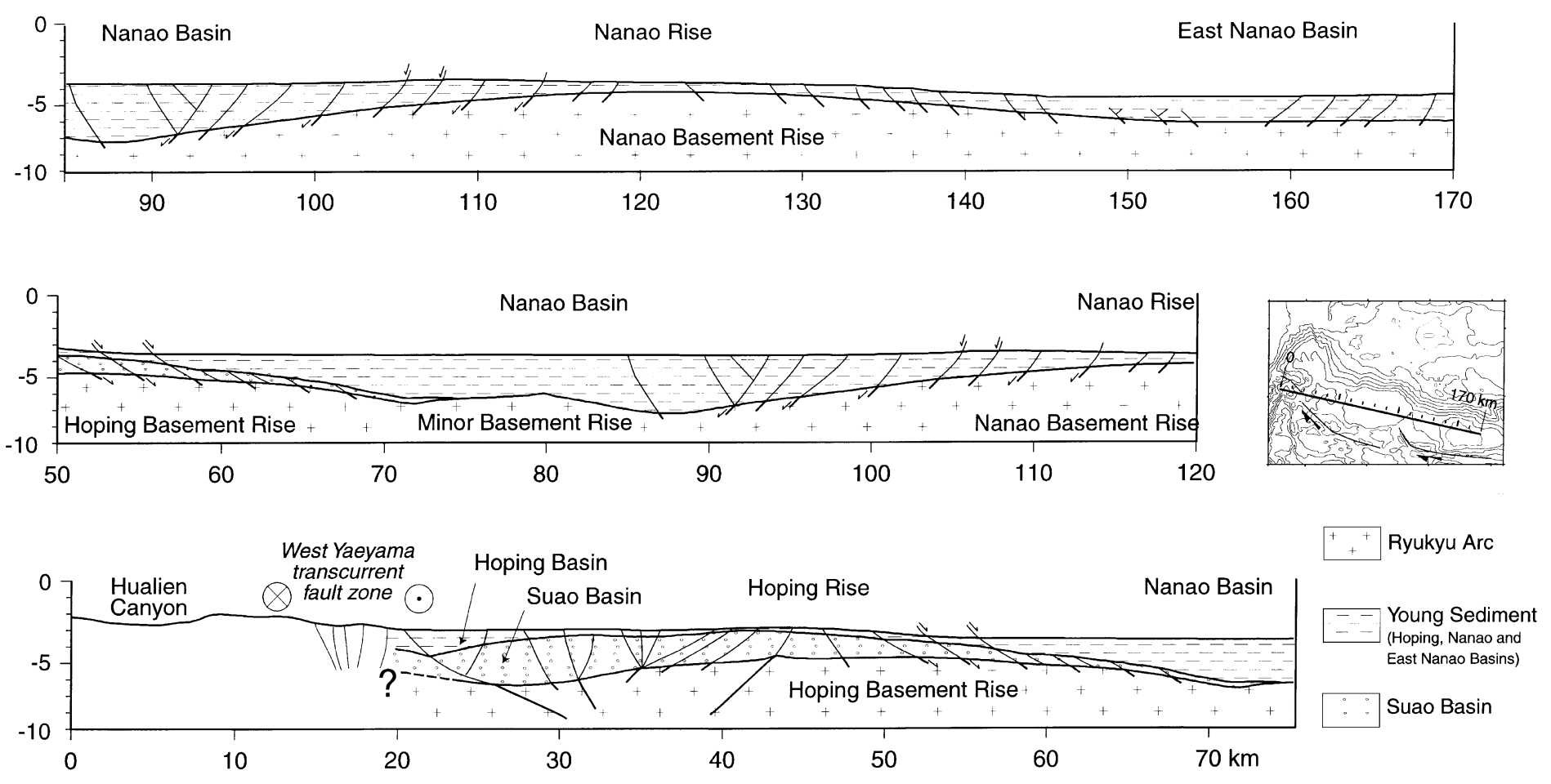

Fig. 10. True scale cross-section (in km) showing observed forearc basin structures along seismic line Ew-14. The profile has been divided into three parts that overlap each other. 


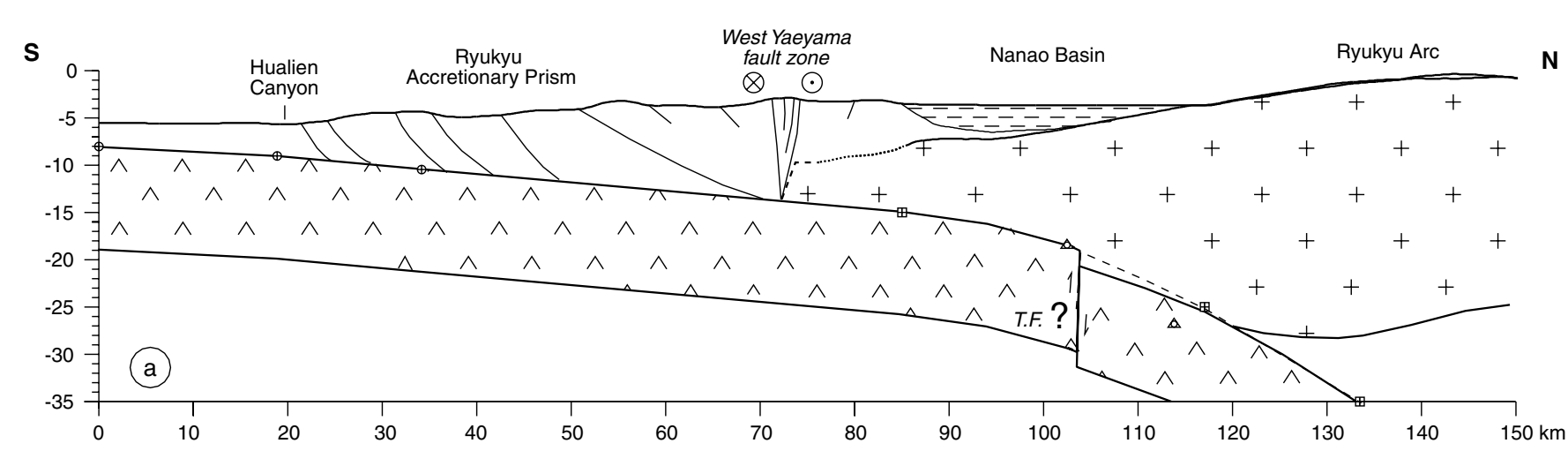

\begin{tabular}{|lllll}
\hline P & Philippine Sea Plate & & & Seismicity (Kao et al., 1998)
\end{tabular}

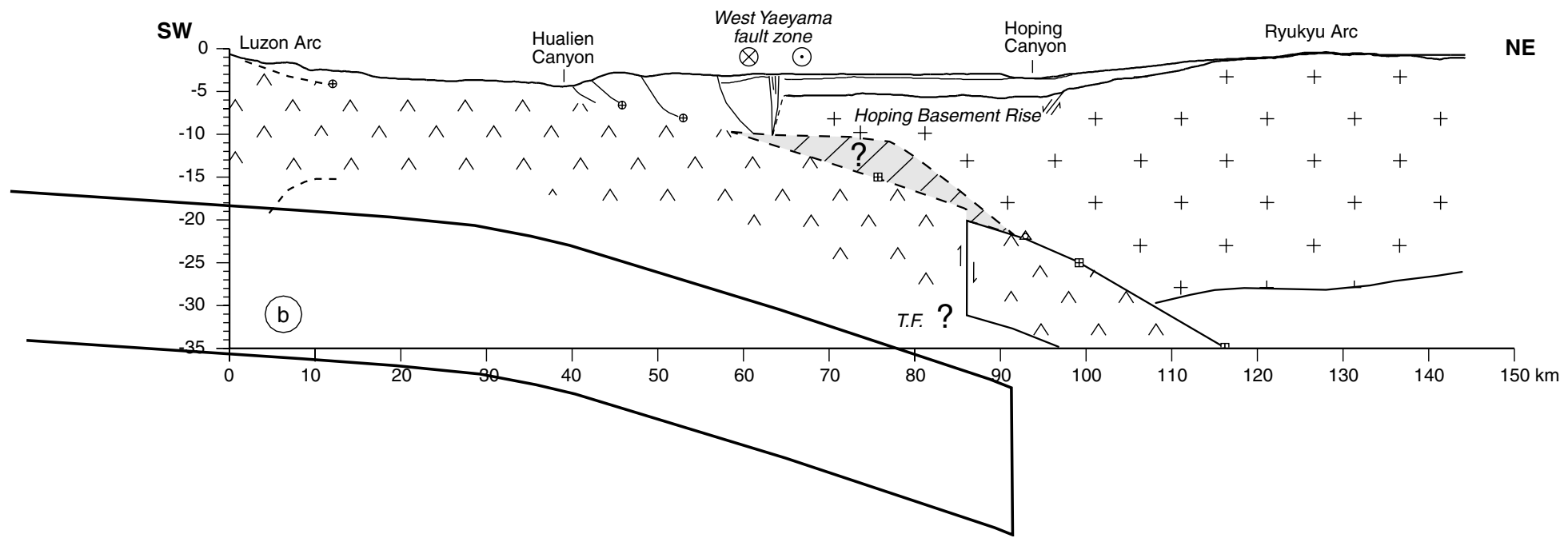

Fig. 11. True scale cross-sections showing structures of the Ryukyu subduction zone along: (a) seismic profile 446-05; and (b) seismic profile Ew-01. The top of the subducting Philippine Sea plate is traced from published data (references in figure) and seismic reflection data. 
uplift hasn't totally ceased during the deposition of the Hoping Basin. Normal faults (presumably related to the Hoping uplift) cutting all the way from the basement to the Hoping Basin strata confirm this hypothesis. However, the same normal faults did not deform the overlying young sediments of the Nanao Basin. This suggests that the uplift of the eastern part of the Hoping rise ceased before the deposition of the Nanao Basin.

\subsection{Southernmost extremity of the Ryukyu arc basement and implications}

The Ryukyu basement reflection is never visible south of and below the West Yaeyama and Yaeyama transcurrent fault zone. We then assume that the transcurrent fault is closely related to the southern end of the Ryukyu Arc basement, probably in the form of a sub-vertical or highly dipping surface. The location of the linear transcurrent fault zone can thus be correlated to the southern boundary of the Ryukyu Arc basement and thus defines the surface projection of its southernmost termination.

Two true scale cross sections that run across the Ryukyu Trench-forearc system in the study area (Fig. 11) are constructed based on all the structural information we could gather. In the upper $10 \mathrm{~km}$, the information include the geometry of the top of the Ryukyu basement established in this study and the seismic reflection profile data recorded south of the forearc basins. Results from seismic refraction profiles (McIntosh and Nakamura, 1998; Wang and Chiang, 1998) and natural seismicity (Kao et al., 1998) are used to constrain the lower part of the cross sections (from 10 to $35 \mathrm{~km}$, location of the top of the Philippine Sea plate, thickness of the Philippine Sea crust and of the Ryukyu Arc). The hypothetical tear fault proposed by Lallemand et al. (1997a) is drawn on the Philippine Sea plate.

The cross section shown in Fig. 11a is located between $23^{\circ} \mathrm{N}$ and $24^{\circ} 30^{\prime} \mathrm{N}$ along the seismic profile Ew-01. Based on the hypothesis that the transcurrent fault zone is nearly vertical and that no sediments are dragged down with the subducting plate below the Ryukyu Margin, the frontal shape of the backstop should look like a vertical wall (Fig. 11a). This 'wall' is presently $4.5 \mathrm{~km}$ high. Independently, two years earlier, Dominguez et al. (1998) needed to use such a backstop geometry in sandbox modeling to reproduce a linear transcurrent fault at the rear of the accretionary prism. Such backstop termination geometry is out of the ordinary and might result either from truncation or/and uplift derived from material stacking.

Two hypothetical mechanisms are proposed to explain the truncation. In the first hypothesis, the obliquity of the subduction and the resulting partitioning that caused transcurrent faulting might have truncated the toe of the Ryukyu backstop and dragged it laterally.

In the second hypothesis, the mechanism is related to the Luzon Arc indentation on the passive margin. We suppose that the Luzon Arc expands further north on the subducted plate. A few million years ago, when the buoyant Luzon Arc met and obliquely subducted the Ryukyu Margin, it could have tear and carry away the frontal toe of the Ryukyu basement. In this case, the Hoping uplift corresponds to a small offscrapped part of the subducting Luzon Arc.

In both cases, we can wonder where the toe of the backstop isolated in such a way did go? Several hypotheses can be stated. The material could have subducted below the margin. It could either be dragged laterally (westward) and, then subducted, thus creating the Hoping uplift or could be stacked (or underplated) below the backstop.

Fig. $11 \mathrm{~b}$ is located along seismic profile 446-05 that runs through the 'Hoping uplift'. In this section, the distance between the top of the Ryukyu Arc basement and the Philippine Sea plate is more than $6 \mathrm{~km}$. The subduction (or underplating) of an asperity could explain the uplift the overlying backstop and produce the observed geometry (Fig. 11a and b). The asperity could be a seamount, a detached block of the Luzon Arc or the isolated frontal toe of the Ryukyu Margin.

\subsection{Basement geometry and bayonet shape}

We assume that the morphology of the very linear transcurrent fault zone defines the surface projection of the southernmost termination of the Ryukyu Arc. The change in strike of the shear zone (Yaeyama fault zone) is surprisingly similar to the change in strike of the Ryukyu Arc southern slope east of $122^{\circ} 40^{\prime} \mathrm{E}$ (bayonet, see Figs. 2 and 9). It is difficult to think that this similarity is only a coincidence and thus, this observation strongly supports the hypothesis 
that the morphology of the transcurrent fault system delineates the geometry of the backstop toe. This assumption leads one to reconsider the basement geometry.

There is a separation of about $20 \mathrm{~km}$ between the westernmost end of the Yaeyama fault and the easternmost end of the West Yaeyama fault (Figs. 2 and 9). As the forearc basement is not be observed on the seismic profiles that run across this gap, we suggest that the jump between the transcurrent fault zones reflects an offset in the basement. Further, the curved shape of the Yaeyama fault zone suggests that the basement underwent some strong deformation in this area. Thus, the offset in the basement probably reflects a regional scale deformation whose origin is still ambiguous.

Hsu et al. (1996) in his model proposes that the bayonets seen on the Ryukyu Arc southern slope correspond to NW-SE right-lateral strikeslip faults. These faults would have developed during the indentation and faulting of the Ryukyu Arc by the buoyant Luzon Arc prior to the orogeny of the proto-Taiwan. Indeed, the trend of the faults proposed by Hsu et al. (1996) is consistent with the trend of the curved segment of the Yaeyama fault zone.

The intricate geometry displayed by the Yaeyama fault zone and the bayonet arc-slope is of interest. The bayonet Ryukyu Arc slope is located exactly north of the Yaeyama fault zone and the parallelism between the two of them are remarkable (Fig. 9). This observation suggests that, not only the toe of the backstop is deformed but the whole Ryukyu forearc basement is also deformed in the same fashion.

An intriguing observation concerns the offset direction of the Ryukyu slope west of the $\mathrm{N} 310^{\circ}$-trending bayonet, on one hand, and the offset of the basement toe west of the Yaeyama fault, on the other hand (Fig. 9). West of $122^{\circ} 40^{\prime} \mathrm{E}$, the slope of the arc is shifted $15 \mathrm{~km}$ northward. However, the transcurrent fault, which is supposed to occur along the Ryukyu basement toe, is shifted $10 \mathrm{~km}$ southward. This southward advance of the southernmost extremity of the Ryukyu Arc basement could be explained by the existence of some additional material beneath the frontal portion of the Ryukyu Arc basement. This observation thus favors the hypothesis of stacking (or/and underplating) of the isolated toe of the backstop beneath the frontal part of the Ryukyu Arc basement west of $122^{\circ} 40^{\prime} \mathrm{E}$.

\section{Conclusions}

The southernmost Ryukyu margin east of Taiwan has been affected by the initiation and evolution of the arc-continent collision processes. This study presents an image of the Ryukyu Arc basement beneath the forearc basins and provides new constraints on the tectonic development of the region.

Observations on the southern termination of the Ryukyu Arc basement lead us to infer that the transcurrent fault system that lies along the rear of the accretionary prism defines the surface projection of the toe of the backstop. The fact that the strike of the fault zone is exactly parallel to the strike of the Ryukyu Arc slope strongly supports this hypothesis. Viewing from vertical cross-sections perpendicular to the strike of the transcurrent faults, the backstop ends as a near-vertical wall of more than $4.5 \mathrm{~km}$ high. We propose that this unusual backstop geometry is due to the truncation of the toe of the Ryukyu basement. An intriguing observation concerning the location of the Yaeyama and West Yaeyama fault relatively to the Ryukyu Arc slope east and west of the bayonet could be explained by the stacking of some material (i.e. the toe of the Ryukyu backstop isolated by truncation) beneath the Ryukyu margin, west of $122^{\circ} 40 \mathrm{E}$.

One of the main results from this study is the recognition of a raised forearc basement between the Hoping and Nanao Basins that could be formed by subducting or underplating a local asperity carried in by the Philippine Sea plate. The nature of the asperity is still enigmatic. The possible candidates could be an isolated asperity, a detached block of the Luzon Arc or the frontal toe of the Ryukyu Arc truncated by some prior tectonics events and dragged laterally. We propose that the truncation could be related to: (1) partitioning due to oblique subduction that affects the Ryukyu Margin; or (2) the effects of a buoyant arc subducting obliquely.

Owing to the lack of time constraints, only a relative chronology concerning tectono-sedimentary events of the region has been described. We propose new chronological constraints to complement the prior study. The Hoping tectonic uplift occurred 
after the deposition of the Suao Basin and was still active during the Hoping Basin deposition. The uplift tectonic activity has entirely stopped at the time of the deposition of the Nanao Basin. The unconformity between the Hoping and the Suao Basin strata could mark the deposition of the first sediments resulting from the erosion of the Taiwan mountains or some slowing down in the orogen process. However, only deep-sea drilling could confirm or reject this hypothesis.

\section{Acknowledgements}

We thank the captains, crews and technical staffs of the R/V Ocean Researcher I, R/V Maurice Ewing and $\mathrm{R} / \mathrm{V}$ l'Atalante for their help in collecting the seismic data used in this study. Prof. Jacques Angelier and anonymous reviewer are thanked for their constructive comments on the manuscript. Discussions with Honn Kao, Ling-Yun Chiao, Francis Wu and Kirk McIntosh were very helpful in preparing this manuscript. Bradford Hyatt Lee patiently corrected numerous grammatical mistakes in an early version of this manuscript. Liu Shao-Yung, Lin Jia-Ren, Chen Zhi-Xin, Lo Zhen-Ping and Lai Kuo-Rong provided assistance on the intricacies of the Chinese system P.C. Many of the figures are generated using the GMT software of Wessel and Smith. The Ministry of Education, Republic of China kindly provided scholarships to the first author through the office of Bureau de Representation de Taipei en France for her $\mathrm{PhD}$ study in Taiwan. Both the National Science Council and the French Institute in Taiwan support the France-Taiwan cooperation frame in Earth Science. This research was funded by the National Science Council of the Republic of China to C.-S. Liu through grants NSC83-0209-M-002a-031Y, NSC85-2611-M-002-005Y and NSC86-2117-M002a-001-ODP.

\section{References}

Angelier, J., 1986. Geodynamics of the Eurasia-Philippine Sea plate boundary: preface. Tectonophysics 125 (1-3), IX-X.

Angelier, J., Bergerat, F., Chu, H.-T., Lee, T.-Q., 1990. Tectonic analysis and the evolution of a curved collision belt: the Hsüehshan Range, northern Taiwan. Tectonophysics 183, 77-96.
Barrier, E., Angelier, J., 1986. Active collision in eastern Taiwan: the Coastal Range. Tectonophysics 125 (1-3), 9-72.

Biq, C., 1972. Dual-Trench structure in the Taiwan-Luzon Region. Proc. Geol. Soc. China 15, 65-75.

Cheng, W.-B., Wang, C., Shyu, C.-T., 1996. Crustal structure of the northeastern Taiwan area from seismic refraction data and its tectonic implications. Terre Atmos. Oceanic Sci. 7 (4), 467-487.

Deschamps, A., Lallemand, S.E., Collot, J.-Y., 1998. A detailed study of the Gagua Ridge: a fracture zone uplifted during a plate reorganization in the Mid-Eocene. Mar. Geophys. Res. 20 (5), 403-423.

Deschamps, A., Monie, P., Lallemand, S., Hsu, S.-K., Yeh, J., 2001. Evidence for Early Cretaceous oceanic crust trapped in the Philippine Sea Plate. Earth Planet. Sci. Lett. (in press).

Dominguez, S., Lallemand, S., Malavieille, J., Schnurle, P., 1998. Oblique subduction of the Gagua Ridge beneath the Ryukyu accretionary wedge system - Insight from marine observations and sandbox experiments. Mar. Geophys. Res. 20 (5), $383-$ 402.

Font, Y., 1996. Etude de la sismicité au nord-est de Taiwan: conséquences sur la déformation de la plaque philippine au front de la zone de collision. DEA report, Montpellier University, June 1996.

Font, Y., Lallemand, S., Angelier, J., 1999. Etude de la transition entre l'orogène actif de Taiwan et la subduction des Ryukyu apports de la sismicité. Soc. Géol. Fr 170 (3), 271-283.

Ho, C.-S., 1986. A synthesis of the geologic evolution of Taiwan. Tectonophysics 125, 1-26.

Hsu, S.-K., Sibuet, J.-C., Monti, S., Shyu, C.-T., Liu, C.-S., 1996. Transition between the Okinawa Trough backarc extension and the Taiwan collision: new insights on the southernmost Ryukyu subduction zone. Mar. Geophys. Res. 18, 163-187.

Imanishi, M., Kimata, F., Inamori, N., Miyajima, R., Okuda, T., Takai, K., Hiraha, K., 1996. Horizontal displacements by GPS measurements at Okinawa-Sakishima Islands (1994-1995). Earthquake 2 (49), 417-421 (in Japanese).

Juang, W.-S., Bellon, H., 1984. The potassium-argon dating of andesites from Taiwan. Proc. Geol. Soc. China 27, 86-100.

Kao, H., Shen, S.-S., Ma, K.-F., 1998. Transition from oblique subduction to collision: earthquakes in the southernmost Ryukyu Arc-Taiwan region. J. Geophys. Res. 103, 7211-7229.

Lallemand, S., Liu, C.-S., Font, Y., 1997a. Tear fault boundary between the Taiwan orogen and the Ryukyu subduction zone. Tectonophysics 274, 171-190.

Lallemand, S., Liu, C.-S., and the ACT cruise scientific team, 1997. Swath bathymetry reveals active-arc collision near Taiwan. EOS Trans. Am. Geophys. Union. 78, 173-175.

Lallemand, S., Liu, C.-S., 1998. Geodynamic implications of present-day kinematics in the southern Ryukyus. J. Geol. Soc. China 41 (4), 551-564.

Lallemand, S., Liu, C.-S., Dominguez, S., Schnle, P., Malavieille, J., and the ACT scientific crew, 1999. Trench-parallel stretching and folding of forearc basins and lateral migration of the accretionary wedge in the southern Ryukyus: a case of strain partition caused by oblique convergence. Tectonics 18 (2), 231-247.

Liu, C.-S., Liu, S.-Y., Lallemand, S., Lundberg, N., Reed, D., 1998. Digital elevation model and its tectonic implications. Terre Atmos. Oceanic Sci. 9 (4), 705-738. 
McIntosh, K.D., Nakamura, Y., 1998. Crustal structure beneath the Nanao forearc basin from TAICRUST MCS/OBS Line 14. Terre Atmos. Oceanic Sci. 9 (3), 345-362.

Malavieille, J., Lallemand, S.E., Dominguez, S., Deschamps, A., Lu, C.-Y., Liu, C.-S., Schnürle, P., and the ACT scientific crew, 2001. Geology of the arc-continent collision in Taiwan: marine observations and geodynamic model. Geol. Soc. Am. Spec. (in press).

Park, J.-O., Tokuyama, H., Shinohara, M., Suyehiro, K., Taira, A., 1998. Seismic record of tectonic evolution and backarc rifting in the southern Ryukyu island arc system. Tectonophysics 294, 21-42.

Rau, R.J., Wu, F.T., 1995. Tomographic imaging of lithospheric structures under Taiwan. Earth. Planet. Sci. Lett. 133, 517-532.

Schnurle, P., Liu, C.-S., Lallemand, S., Reed, D., 1998a. Structural controls of the Taitung Canyon in the Huatung basin east of Taiwan. Terre Atmos. Oceanic Sci. 9 (3), 453-472.

Schnurle, P., Liu, C.-S., Lallemand, S., Reed, D., 1998b. Structural insight into the south Ryukyu Margin: effects of the subducting Gagua Ridge. Tectonophysics 288, 237-250.

Sibuet, J.-C., Letouzey, J., Barbier, F., Chavel, J., Foucher, J.-P., Hilde, T.W.C., Kimura, M., Ling-Yun, C., Marsset, B., Müller, C., Stéphan, J.F., 1987. Back-arc extension in the Okinawa trough. J. Geophys. Res. 92, 14042-14063.

Sibuet, J.-C., Hsu, S.-K., Shyu, C.-T., Liu, C.-S., 1995. Structural and kinematic evolutions of the Okinawa Trough back-arc basin. Backarc Basins: Tectonics Magmatism, 343-379.
Sibuet, J.-C., Deffontaines, B., Hsu, S.-K., Thareau, N., Le Formal, J.-P., Liu, C.-S., and the ACT party, 1998. Okinawa trough back-arc basin: early tectonic and magmatic evolution. J. Geophys. Res. 103, 30 245-30 267.

Suppe, J., 1976. Decollement folding in western Taiwan. Pet. Geol. Taiwan 13, 25-25.

Suppe, J., 1981. Mechanics of mountain building and metamorphism in Taiwan. Mem. Geol. Soc. China 4, 67-89.

Teng, L., 1990. Geotectonic evolution of late Cenozoic arc-continent collision in Taiwan. Tectonophysics 183, 57-76.

Teng, L., Chen, C.-H., Wang, W.-S., Liu, T.-K., Juang, W.-S., Chen, J.-C., 1992. Plate kinematic model for late Cenozoic arc magmatism in northern Taiwan. J. Geol. Soc. China 36 (1), 1-18.

Yu, S.-B., Chen, H.-Y., Kuo, L.-C., 1997. Velocity field of GPS stations in the Taiwan area. Tectonophysics 274, 41-59.

Yu, S.-B., Kuo, L.-C., 1999. GPS observation of crustal deformation in the Taiwan-Luzon region. Geophys. Res. Lett. 26 (7), 923-926.

Wang, T.K., Chiang, C.-H., 1998. Imaging of arc-arc collision in the Ryukyu forearc region offshore Hualien from TAICRUST OBS line 16. Terre Atmos. Oceanic Sci. 9 (3), 329-344.

Wu, F.T., 1978. Recent tectonics of Taiwan. J. Phys. Earth 26, 265 299.

Wu, F.T., Rau, R.-J., Slazberg, D., 1997. Taiwan orogeny: thinskinned or lithospheric collision? Tectonophysics 274, 191-220. 